
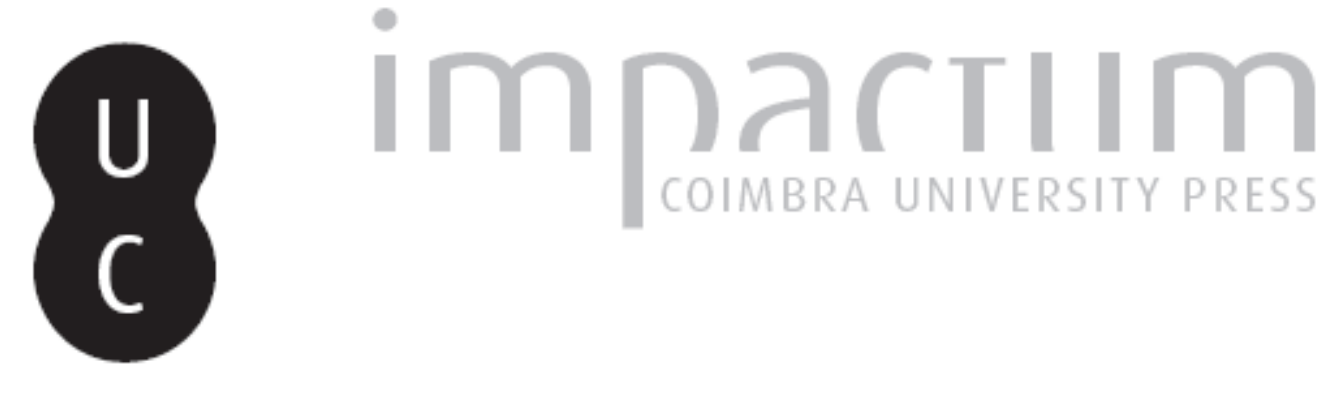

\title{
Riscos de incêndios florestais no parque nacional de Brasília. Brasil
}

\author{
Neto, Gervásio Barbosa Soares; Bayma, Adriana Panhol; Faria, Karla \\ Autor(es): $\quad$ Maria Silva de; Oliviera, Erivan Germano de; Menezes, Paulo Henrique \\ Bretanha Junker
}
Publicado por: $\quad$ Associação Portuguesa de Riscos, Prevenção e Segurança; Imprensa da Universidade de Coimbra

URL

persistente: URI:http://hdl.handle.net/10316.2/39758

DOI: ～DOI:https://doi.org/10.14195/1647-7723_23_13

Accessed : $\quad$ 26-Apr-2023 12:19:33

A navegação consulta e descarregamento dos títulos inseridos nas Bibliotecas Digitais UC Digitalis, UC Pombalina e UC Impactum, pressupõem a aceitação plena e sem reservas dos Termos e Condições de Uso destas Bibliotecas Digitais, disponíveis em https://digitalis.uc.pt/pt-pt/termos.

Conforme exposto nos referidos Termos e Condições de Uso, o descarregamento de títulos de acesso restrito requer uma licença válida de autorização devendo o utilizador aceder ao(s) documento(s) a partir de um endereço de IP da instituição detentora da supramencionada licença.

Ao utilizador é apenas permitido o descarregamento para uso pessoal, pelo que o emprego do(s) título(s) descarregado(s) para outro fim, designadamente comercial, carece de autorização do respetivo autor ou editor da obra.

Na medida em que todas as obras da UC Digitalis se encontram protegidas pelo Código do Direito de Autor e Direitos Conexos e demais legislação aplicável, toda a cópia, parcial ou total, deste documento, nos casos em que é legalmente admitida, deverá conter ou fazer-se acompanhar por este aviso.
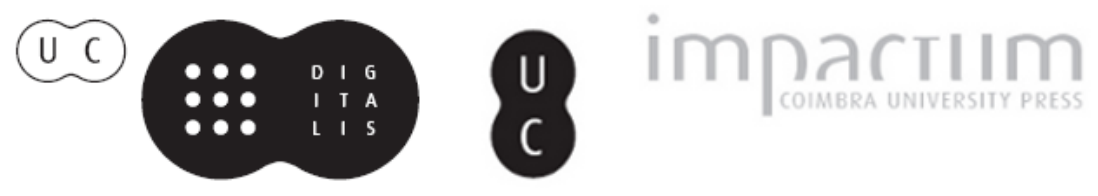


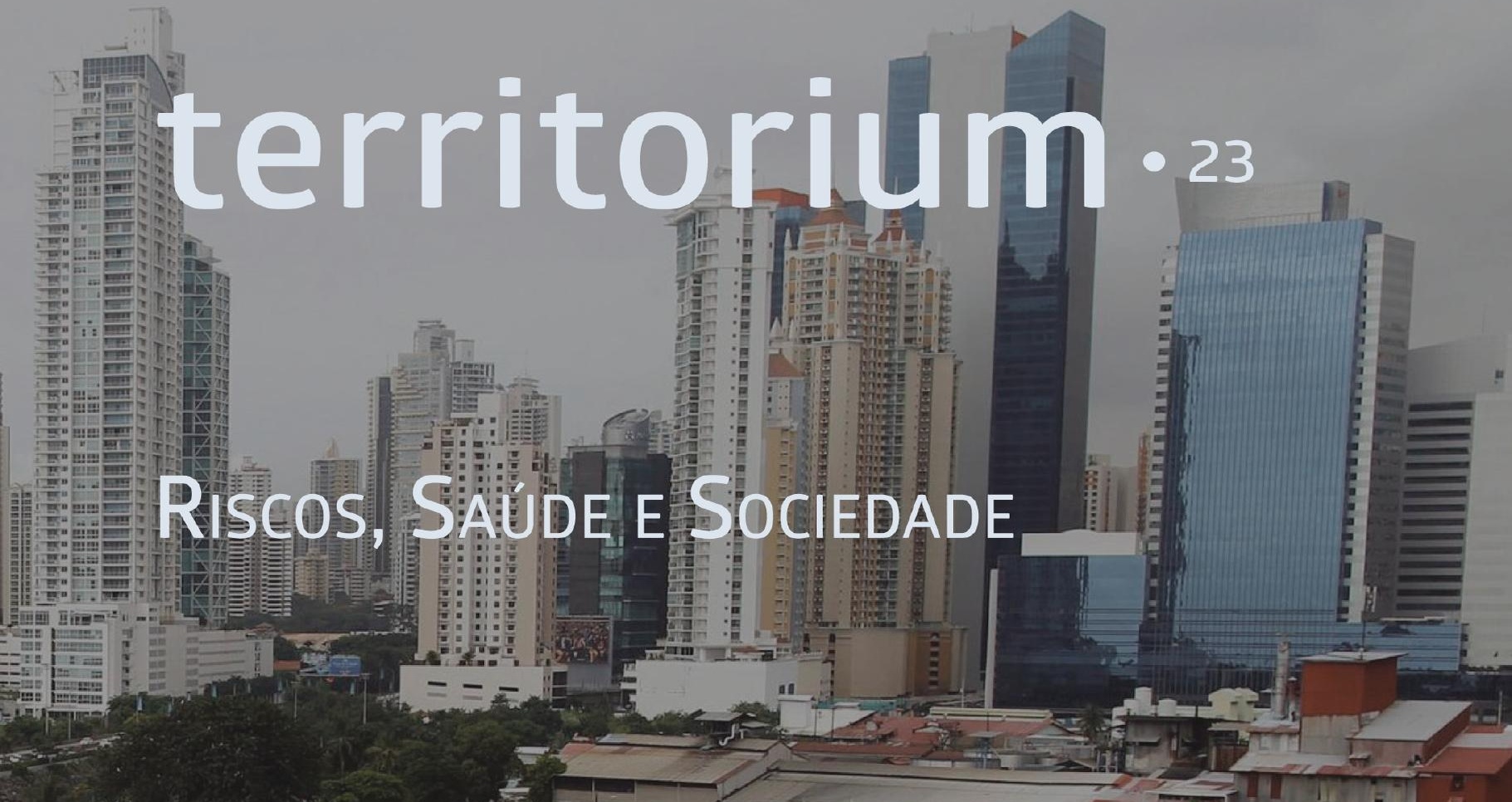

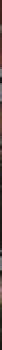

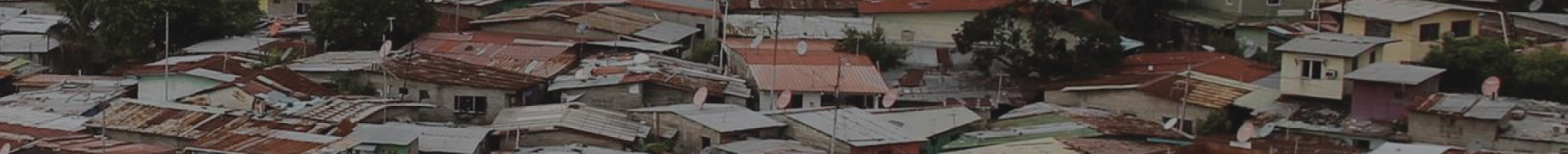

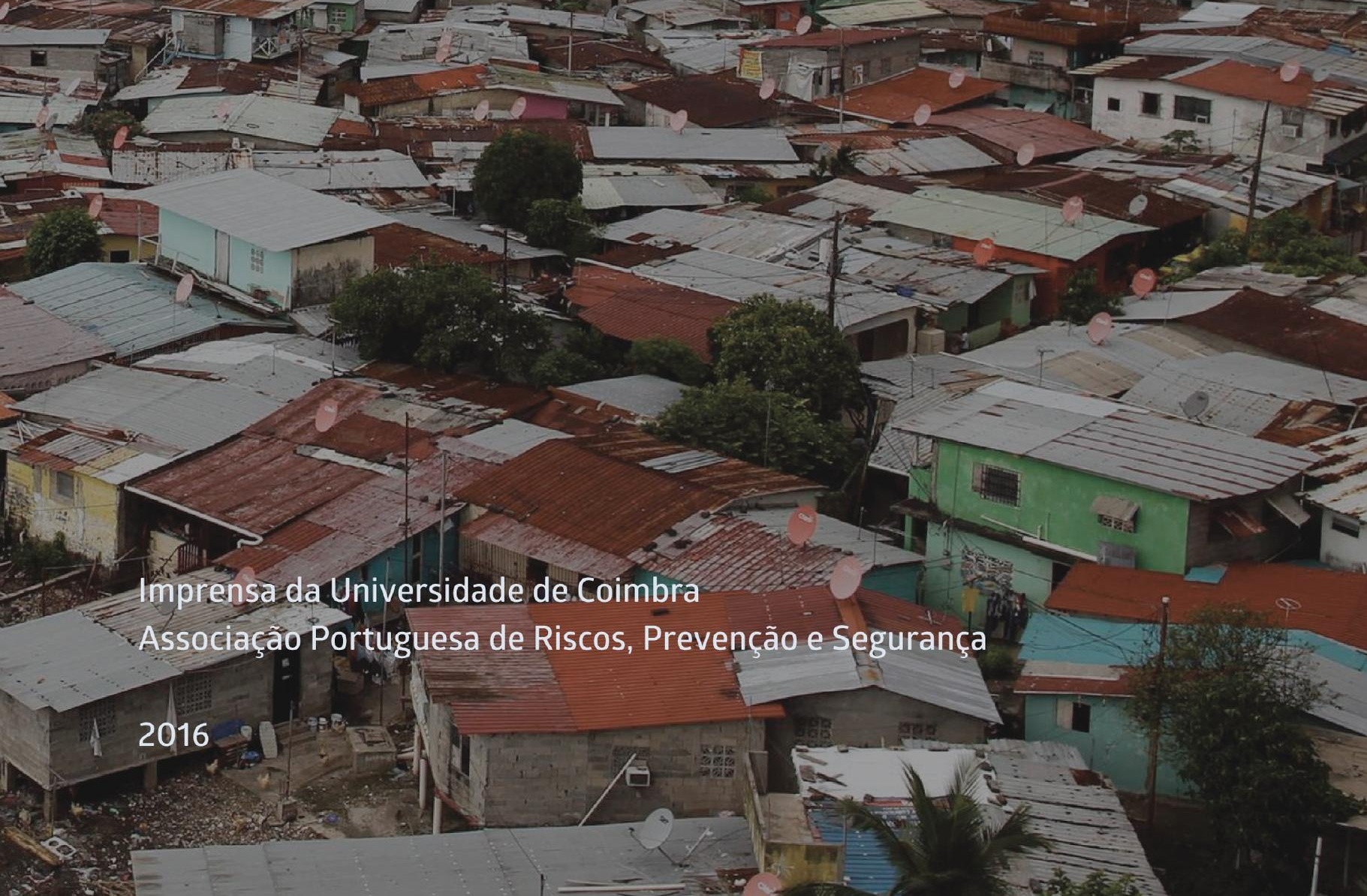




\section{RISCOS DE INCÊNDIOS FLORESTAIS NO PARQUE NACIONAL DE BRASÍLIA - BRASIL*}

FOREST FIRE RISKS IN THE BRASILIA NATIONAL PARK - BRAZIL

\author{
Gervásio Barbosa Soares Neto \\ Instituto Federal de Brasília \\ gervasio.neto@etfbsb.edu.br \\ Adriana Panhol Bayma \\ Ministério do Meio Ambiente \\ Secretaria de Biodiversidade e Florestas \\ adriana.bayma@mma.gov.br
}

Karla Maria Silva de Faria

Instituto de Estudos Sócio Ambientais Universidade Federal de Goiás, Brasil karlamsfaria@gmail.com

Erivan Germano de Oliviera

Universidade de Brasília erivan_germano@yahoo.com.br

Paulo Henrique Bretanha Junker Menezes

Universidade Federal de Alfenas paulo.menezes@unifal-mg.edu.br

\section{RESUMO}

O objetivo deste trabalho foi o de definir um modelo de risco de incêndio e um mapa estratégico de combate a incêndio florestal com base em Sistema de Informações Geográficas (SIG) para o Parque Nacional de Brasília, situado a noroeste do Distrito Federal/Brasil. Foram consideradas variáveis como uso e ocupação do solo, declividade do terreno, orientação das encostas e rede viária. Os resultados indicaram que $83 \%$ da área do Parque encontravam-se sob risco alto e muito alto de incêndio e que $3 \%$ indicaram risco extremo. A metodologia foi replicada em outras áreas no bioma Cerrado e validada com base em focos de incêndios ocorridos em 2010.

Palavras-chave: SIG, Parque Nacional de Brasília, mapas de risco, risco de incêndio, incêndios florestais.

\section{ABSTRACT}

The objective of this study is to define a model of fire risk and a strategic map of forest fire combat based on the Geographic Information System (GIS) for the Brasília National Park, located in the northwest of the Federal District, Brazil. Many variables were considered such as the terrain's slopes, declivity, road network, land use and occupation, the tilt and orientation of the terrain and roads. The results indicated that $83 \%$ of the National Park area are under high risk or very high risk of fire and $3 \%$ are under extreme risk. The methodology has been replicated in other areas in the Cerrado biome and validated in fire zones in 2010.

Keywords: Geographical information system, Brasilia National Park, risk maps, fire risk, forest fire.

\section{RESUMEN}

Riesgos de Incendios Forestales en el Parque Nacional de Brasilia - Brasil - El objetivo de este estudio es definir un modelo de riesgo de incendio y un mapa estratégico de lucha contra los incendios forestales basado en el Sistema de Información Geográfica para el Parque Nacional de Brasilia, que se encuentra en el noroeste del Distrito Federal/Brasil. Fueron consideradas variables como el uso y ocupación del suelo, la inclinación y orientación del terreno y las carreteras. Los resultados indican que el $83 \%$ del área del Parque está bajo riesgo alto y muy alto de fuego y el 3\% en riesgo extremo. La metodología ha sido replicada en otras áreas en el Cerrado y validado en zonas de un incendio de 2010.

Palabras clave: SIG, Parque Nacional de Brasilia, mapas de riesgo, riesgos de incendio.

\section{RESUMÉ}

Les risques d'incendie de forêt dans le Parc National de Brasilia - Brésil - À partir de cette étude, nous cherchons à tracer un modèle de risque d'incendie et d'une carte stratégique de lutte contre les incendies de forêt dans le Parc National de Brasília, situé à nord-ouest du Distrito Federal (au Brésil). Cette modélisation est basée sur le Système d'Information Géographique (SIG) et prend en compte des variables telles que: l'usage et l'occupation du terrain, la déclivité de la superficie, l'orientation des versants et le réseau routier. Les résultats montrent que $83 \%$ du terrain du parc est soumis à un grand risque et très grand risque d'incendie et $3 \%$ présentent un risque extrême. La méthodologie employée pour cette étude a été déjà utilisée dans d'autres zones du biome Cerrado et validée pendant les incendies qui ont eu lieu en 2010.

Mots-clé: SIG, Parc National de Brasília, plan de risque, risque d’incendie, incendie de forêt.

* O texto deste artigo corresponde a uma comunicação apresentada no I Seminário da Rede Incêndios-Solo e I Simpósio Ibero-Afro-Americano de Riscos, tendo sido submetido em 19-11-2015, sujeito a revisão por pares a 18-03-2016 e aceite para publicação em 31-03-2016.

Este artigo é parte integrante da Revista Territorium, n. ${ }^{\circ} 23,2016,{ }^{\circ}$ RIscos, ISSN: 0872-8941. 


\section{Introdução}

Muitos ecossistemas terrestres mantêm uma relação de dependência do fogo para manutenção de sua biodiversidade, como por exemplo as savanas. Neles, as espécies se adaptaram tanto fisiológica como morfologicamente para enfrentarem episódios de ocorrência natural de fogo, devidos a fatores meteorológicos. No entanto, o aumento na frequência e na intensidade do regime de fogo - em grande medida de causa antrópica - vem causando a destruição da vida nestes ecossistemas. De acordo com Lierop et al. (2015), entre 2003 e 2012, aproximadamente 67 milhões de hectares $(1.7 \%)$ de florestas queimaram anualmente, principalmente na região tropical da América do Sul e da África.

No Brasil, a maior parte da ocorrência de incêndios ocorre no bioma Cerrado, tipo de savana, situado na região central do Brasil. O Cerrado tem uma área aproximada de 2,1 milhões de $\mathrm{km}^{2}$, que corresponde a $24,25 \%$ do território nacional (EMBRAPA, 1994). A vegetação do Distrito Federal é caracterizada exclusivamente pelo cerrado. Porém, nos últimos anos houve um processo acelerado de ocupação sobre a região com o aumento da densidade demográfica, onde pode-se citar a consolidação geopolítica de Brasília na sua parte central e expansão da agricultura intensiva (Almeida, 1997). Torna-se importante ressaltar que as áreas do Parque Nacional de Brasília apresentam-se extremamente pressionadas em função do acelerado processo de ocupação do solo ao redor dessas áreas, nem sempre planejado e organizado.

No período de estiagem, entre os meses de maio e setembro, a temperatura elevada e a baixa da umidade relativa do ar favorecem a propagação de incêndios florestais, mobilizando o setor público nas atividades de combate e prevenção aos incêndios. Dias (1992) afirma que as queimadas têm seu começo em maio, início da estação seca, onde a umidade relativa começa a decair chegando a atingir em agosto valores inferiores a $20 \%$ nas horas mais quentes do dia. A propagação do fogo é favorecida, por ser este período o que mais proporciona o acúmulo de biomassa combustível, oriunda da morte das partes aéreas do estrato herbáceo/subarbustivo e as quedas das folhas de arbustos e árvores.

O Sistema de Informações Geográficas (SIG) é indispensável para o mapeamento dos riscos de incêndios, pois fornece informações diferenciadas de acordo com cada tipo de região, utilizando fatores inerentes ao uso da terra, cobertura vegetal e características do relevo. Com as informações oferecidas pelos mapas de risco de incêndios, várias medidas podem ser tomadas para reduzir a ocorrência de incêndios florestais, como por exemplo: maior vigilância nas áreas de risco, restrição de acesso a esses locais, construção de aceiros preventivos. Também podem ser tomadas medidas de auxílio ao combate, como construção de estradas de acesso rápido aos locais de risco e alocação de recursos de combate em pontos estratégicos (Ferraz; Vetorazzi, 1998).

A área de estudo foi o Parque Nacional de Brasília (PNB), situado na porção noroeste do Distrito Federal, a cerca de $10 \mathrm{~km}$ do centro de Brasília, escolhido para a utilização desta metodologia que teve como objetivo identificar as áreas de maior risco de incêndio florestal nesta unidade de conservação. A criação do Parque surgiu da necessidade de se proteger os rios fornecedores de água potável para a Capital Federal e de manter a vegetação em seu estado natural. Nos últimos anos, os longos períodos de estiagem associados às ações antrópicas, com queima para limpeza e prática de queimadas criminosas, têm levado o aumento de ocorrência de incêndios florestais na região do Parque, o que fez surgir a necessidade de criar um modelo que classificasse as áreas de maior risco de incêndio, a fim de minimizar os efeitos do fogo. De acordo com Medeiros e Fiedler (2003), a ocorrência de grandes incêndios florestais em Unidades de conservação é considerada uma grave ameaça para a conservação da biodiversidade e manutenção de processos ecológicos.

Quando um pequeno foco nãoé controlado imediatamente, o incêndio é estabelecido e seu combate é dificultado por vários fatores, como: tamanho do fragmento; falta de recursos próprios de combate; demora na detecção; falta de acessos adequados etc. Assim, a utilização de técnicas de prevenção de incêndios, bem como a realização de um planejamento estratégico de combate, são alternativas viáveis para a redução da ocorrência de incêndios. (Ferraz; Vetorazzi, 1998)

Muitas são as iniciativas de utilização de SIG para mapeamentos de áreas suscetíveis à incêndios, como forma de se otimizar a utilização dos recursos para combate, melhorar práticas que evitem o início e a propagação dos incêndios a fim de que os danos causados ao homem e ao meio ambiente sejam os menores possíveis.

A utilização de SIG para o mapeamento das áreas de risco de incêndios florestais permitirá aos órgãos responsáveis pela proteção dos recursos naturais a identificarem quais são as áreas mais suscetíveis a ocorrências deste tipo, contribuindo na adoção de medidas preventivas e que facilitem o combate em caso de deflagração de focos (Batista, 2000).

Muito se avançou na aquisição de recursos voltados para o combate aos incêndios florestais no Distrito Federal, como compra de aeronaves, viaturas equipadas com equipamentos próprios para o combate florestal, equipamentos de proteção individual para os bombeiros combatentes, porém, a maior eficiência destes depende de um planejamento estratégico para utilizá-los. 
Desta forma, o principal enfoque deste artigo foi a utilização de geotecnologias aplicada ao combate a incêndios florestais no Parque Nacional de Brasília para mapear as áreas de maior risco de ocorrência de incêndios, visando à otimização dos recursos disponíveis para o combate nos períodos de longa estiagem.

\section{Materiais e Métodos}

\section{Área de Estudo}

O Parque Nacional de Brasília situa-se na porção noroeste do Distrito Federal (DF), na região Administrativa Plano Piloto, entre os paralelos $15^{\circ} 35^{\prime}$ e $15^{\circ} 45^{\prime}$ (latitude sul) e meridianos $47^{\circ} 53^{\prime}$ e $48^{\circ} 05^{\prime}$ (longitude oeste). A área original do Parque, criado em 1961, era de cerca de 30.000 hectares; porém, a Lei $n^{\circ} 11.285$ de 8 de março de 2006 alterou sua área para 42.389,01 hectares (quarenta e dois mil, trezentos e oitenta e nove hectares e um centésimo), (fig 1). No entanto, a área deste estudo consiste na área sem ampliação, englobando, porém, áreas urbanas do entorno do Parque em um raio de $2 \mathrm{~km}$. Abriga além da fauna e flora típicas do cerrado, a Barragem de Santa Maria, responsável por parte do abastecimento de água potável da capital brasileira.

\section{Base de Dados}

Para desenvolvimento e elaboração dos produtos obtidos, foram necessários o uso de softwares que possibilitaram a integração de dados geográficos e a compilação de bases de dados que permitiram a análise e interpretação dos elementos necessários para a representação fisionômica da área estudada. Assim, a base e os softwares usados foram:
- Mapa de vegetação escala 1:25.000 (Fonte: Terracap - Companhia Imobiliária de Brasília)

- Mapa de vias de Brasília escala 1:25.000 (Fonte Terracap - Companhia Imobiliária de Brasília)

- Mapa de Hidrografia de Brasília escala 1:25.000 (Fonte: Terracap - Companhia Imobiliária de Brasília)

- Curvas de nível com equidistância de 5 metros (Fonte: Terracap - Companhia Imobiliária de Brasília)

- Pontos Cotados em escala 1:25.000 (Fonte: Terracap - Companhia Imobiliária de Brasília)

- Imagem Landsat 5 sensor TM do dia15/09/2007 (Fonte: INPE - Instituto Nacional de Pesquisas Espaciais)

- Imagem Landsat 5 sensor TM do dia 23/09/2010 (Fonte: INPE - Instituto Nacional de Pesquisas Espaciais)

- $\quad$ Software Arcgis 9.3

- $\quad$ Envi 4.7

\section{Mapa de risco de incêndio Florestal}

Todos os dados utilizados no formato shapefile foram posteriormente transformados em raster, para a realização da álgebra de mapas. Toda a base de dados processada está definida com Datum Sirgas 2000 UTM ZONA 23S, na escala 1: 25000. As imagens Landsat 5 TM possuem resolução espacial de 30 metros, com exceção da banda 6 (banda termal), com 120m, sendo a frequência para a obtenção desses dados de 16 dias. As
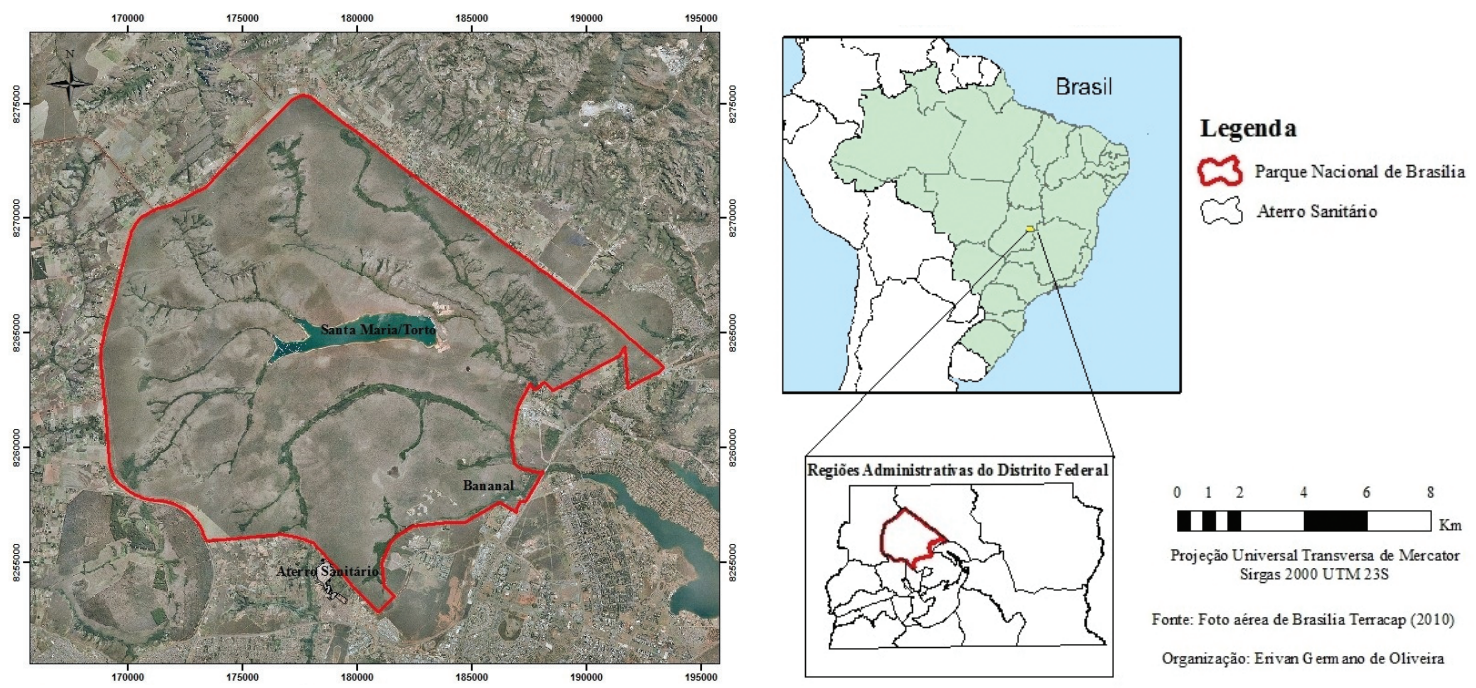

Fig. 1 - Mapa de Localização da área de estudo.

Fig.1 - Map of the study area. 
imagens foram georreferenciadas utilizando-se o método de coleta de pontos de controle.

A metodologia consistiu na elaboração de mapas de risco preliminares para cada variável em estudo: uso e ocupação do solo, estradas, declividade do terreno e orientação das encostas. Ficou estabelecido um buffer de $2 \mathrm{~km}$ a partir do limite do Parque como zona de influência para o surgimento de focos de incêndios. Esta distância foi resultado da análise das propriedades que fazem limite com o Parque e suas atividades, bem como o histórico de queimadas (fig. 2).

Em seguida, estes mapas foram integrados com o auxílio de um modelo de ponderação que indicou a importância de cada variável para a ocorrência e propagação dos incêndios no Parque.

Cada grupo é composto por uma série de variáveis e cada variável possui seu coeficiente que registra maior ou menor importância em relação à deflagração do fenômeno de incêndio. De acordo com Oliveira (2004), as variáveis foram classificadas variando de 0 a 5 (nulo, baixo, moderado, alto, muito alto, extremo).

\section{Uso e Cobertura Vegetal}

Este mapa considerou os diversos tipos de uso e ocupação do solo existente no Parque Nacional de Brasília e entorno. As variáveis representam o risco de ocorrência e propagação dos incêndios florestais, de acordo com a combustibilidade de cada material existente.

O plano de informação de uso e ocupação do solo agrupado nas seguintes classes: Área Urbana, Agricultura, Aterro Sanitário, Campo, Cerrado, Mata, Pasto, Reflorestamento e Solo exposto. Cada classe de uso e ocupação do solo foi classificada de acordo com o grau de risco de incêndio adotada na metodologia (TABELA I).

As características do material combustível influenciam diretamente a propagação do fogo. De acordo com Soares (1985), material combustível é qualquer material orgânico, vivo ou morto, no solo, sobre o solo ou acima dele capaz de entrar em ignição e queimar. Entre as características que contribuem para a propagação do fogo, o tamanho das partículas do material combustível tem importância fundamental. Nesse estudo, a classe campo representa o material mais perigoso por causa das
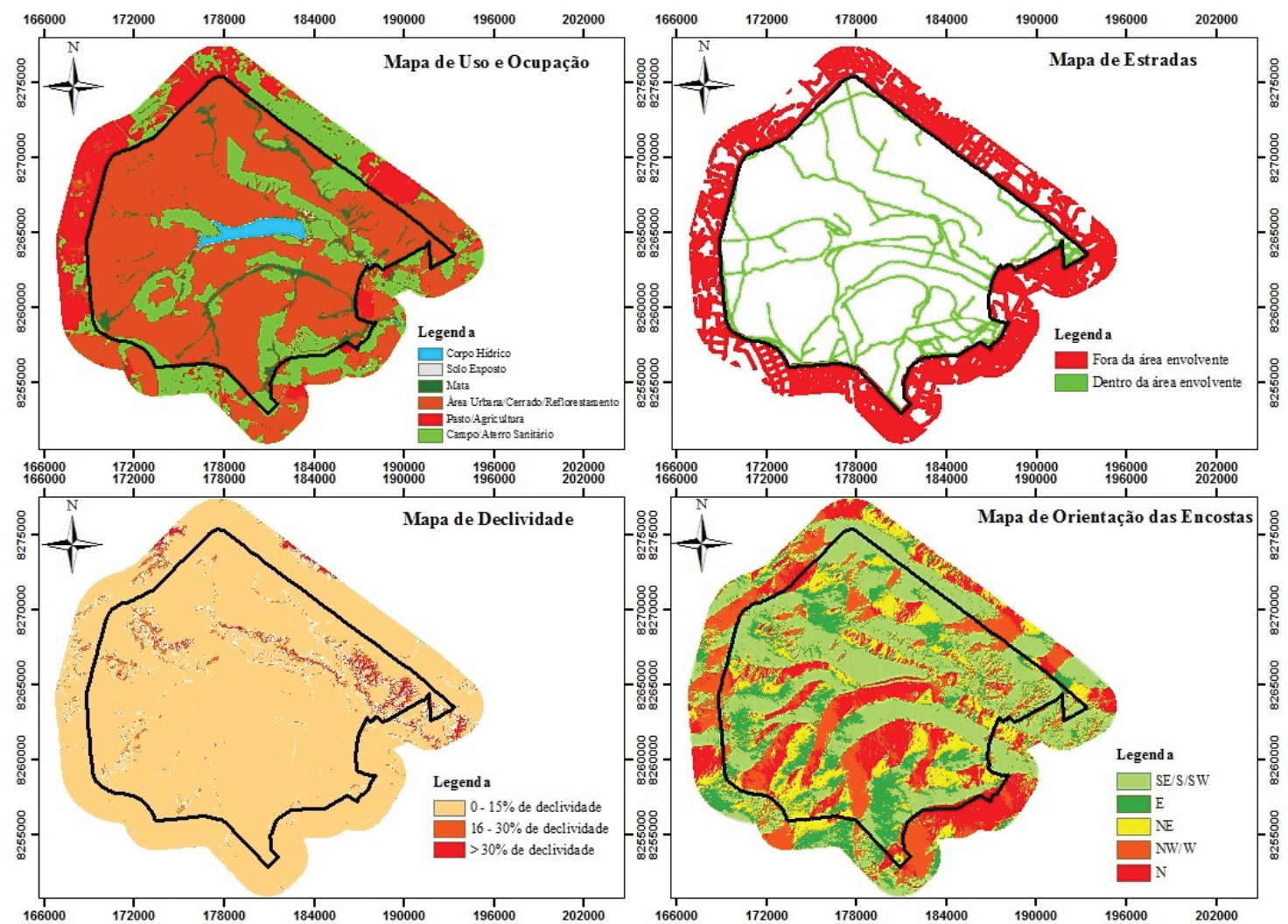

Fig. 2 - Dados de entrada.

Fig. 2 - Input data. 
dimensões das partículas comparado às demais classes de cobertura do solo. O Aterro sanitário localizado na região sul do Parque também foi classificado como de maior risco, tendo em vista a prática de queima de lixo nos limites do Parque.

TABela I - Classificação de risco de incêndio segundo o uso e cobertura vegetal.

TABLE I - Fire risk classification according to the use and vegetation cover.

\begin{tabular}{|l|l|l|}
\hline Uso e Cobertura Vegetal & Risco & Coeficiente \\
\hline Corpo Hídrico & Nulo & 0 \\
\hline Solo Exposto & Baixo & 1 \\
\hline Mata & Moderado & 2 \\
\hline $\begin{array}{l}\text { Cerrado/Reflorestamento/ } \\
\text { Área Urbana }\end{array}$ & Alto & 3 \\
\hline Agricultura/Pastagem/ & Muito alto & 4 \\
\hline Campo/Aterro Sanitário & Extremo & 5 \\
\hline \multicolumn{2}{|c|}{ Fonte: Adaptada de Koproski et al., (2011). } \\
\hline \multicolumn{2}{|c|}{ Source: Adapted from Koproski et al., (2011). }
\end{tabular}

\section{Estradas}

Este plano de informação levou em consideração o acesso de pessoas e veículos no Parque, incêndios criminosos, práticas de pequenas fogueiras, incêndios causados por cigarros, além de outras ocorrências. Determinou-se o raio de influência de cada acesso proporcional ao fluxo de pessoas e veículos que nele transitam. Desse modo, consideraram-se as vias externas como de maior risco, pelo tráfego intenso de pessoas e de veículos, onde foi estipulado um buffer de 100 metros para sua área de influência e classificação de risco extremo (TABELA II).

TABELA II - Classificação de risco de incêndio segundo as estradas

TABLE II - Fire risk classification according to roads.

\begin{tabular}{|l|l|l|}
\hline Estradas & Risco & Coeficiente \\
\hline Dentro da área envolvente & Moderado & 2 \\
\hline Fora da área envolvente & Extremo & 5 \\
\hline
\end{tabular}

As trilhas internas apresentam tráfego de visitantes e funcionários autorizados, sendo proibido o tráfego de pessoas nas trilhas em períodos de alto risco de incêndio. O Parque Nacional de Brasília está sob constante administração e vigilância; a probabilidade de ocorrência de incêndio no seu interior é moderada, mas não descartada, tendo em vista o tamanho do Parque e a impossibilidade de fiscalizar uma área tão grande. Sendo assim, determinou-se um buffer de 30 metros como área de influência das trilhas internas e risco de incêndio moderado.

\section{Declividade}

Este plano considerou a inclinação do terreno como fator de propagação de incêndios. As áreas mais declivosas foram consideradas de maior risco, pois a transferência de calor é facilitada no sentido do aclive, aumentado a velocidade de propagação (TABELA III). O mapa de declividade foi obtido por meio do Modelo Digital de Elevação (MDE) Topogride, modelado a partir das curvas de nível e pontos cotados.

TABELA III - Classificação de risco segundo a declividade.

TABLE III - Risk classification according to slope.

\begin{tabular}{|l|l|l|}
\hline Declividade & Risco & Coeficiente \\
\hline $0-15$ & Baixo & 1 \\
\hline $16-30$ & Alto & 3 \\
\hline$>30$ & Extremo & 5 \\
\hline
\end{tabular}

Fonte: Andrade et al., (2011). Source: Andrade et al., (2011).

\section{Orientação das encostas}

As faces de maior risco são aquelas de maior exposição do sol, contribuindo para a redução da umidade do material combustível. A face Norte é a que oferece risco extremo de incêndio florestal, por estar mais exposta a insolação no período de estiagem (TABELA IV).

O grau de risco de incêndio é determinado pela correlação entre diversas variáveis ambientais que quando associadas dificultam o controle do fogo. Essas

TABELA IV - Classificação de risco segundo a orientação das encostas.

TABLE IV - Risk classification according to the orientation of the slopes.

\begin{tabular}{|c|c|c|c|}
\hline Ângulo de Orientação & Exposição & Risco & Coeficiente \\
\hline $112,5^{\circ}$ a $247,5^{\circ}$ & $\mathrm{SE} / \mathrm{S} / \mathrm{SW}$ & Baixo & 1 \\
\hline $67,5^{\circ}$ a $112,5^{\circ}$ & E & Moderado & 2 \\
\hline $22,5^{\circ} \mathrm{A} 67,6^{\circ}$ & NE & Alto & 3 \\
\hline $247,5^{\circ}$ a $337,5^{\circ}$ & NW/W & Muito Alto & 4 \\
\hline $337,5^{\circ}$ a $22,5^{\circ}$ & $\mathrm{N}$ & Extremo & 5 \\
\hline
\end{tabular}


variáveis podem ser combinadas por equações que traduzem o potencial de ocorrência e a propagação do fogo (Ferreira et al., 2011).

A álgebra de mapas foi realizada no Arcgis 9.3, onde foram somados os coeficientes de risco de cada variável, gerando o mapa de risco de incêndio, com as classes de variação estabelecidas. Neste trabalho, o modelo de integração de dados foi expresso pela equação adaptada de Koproski et al., 2011.

Risco: $40 \mathrm{~V}+30 \mathrm{ES}+20 \mathrm{D}+10 \mathrm{E}$

Sendo:
V: Uso e cobertura vegetal;
ES: Estradas;
D: Declividade;
E: Orientação das encostas.

\section{Resultados e Discussão}

O mapa de risco de incêndio segundo a cobertura vegetal e uso e ocupação do solo, o risco foi registrado em 45.772 mil hectares distribuídos em 9 fitofisionomias, excluindo corpo hídrico, por apresentar risco nulo de incêndio florestal. A classe solo exposto $(0,34 \%)$ foi classificada com risco baixo de incêndio, pela ausência de vegetação. A mata $(5,40 \%)$ foi classificada com risco moderado. 0 cerrado $(55,27 \%)$, reflorestamento $(0,61 \%)$ e a área urbana $(2,83 \%)$ foram classificados com alto risco de incêndio. As áreas de pasto $(8,13 \%)$ e agricultura $(3,4 \%)$ foram classificadas com risco muito alto. 0 campo $(24,20 \%)$ e o aterro sanitário da cidade Estrutural $(0,17)$ foram classificados com risco extremo.
O mapa de declividade apresentou 93,58\% da área de estudo com 0 e $15 \%$ de inclinação e com risco baixo de incêndio, 4,82\% da área com variação de declividade entre 16 e $30 \%$ e alto risco de incêndio, 1,6\% da área com risco extremo de incêndio, com inclinação superior a $30 \%$ de declividade.

O mapa de orientação das encostas indica que $39,20 \%$ foi classificado como risco baixo, compreendendo as classe sudeste, sul e sudoeste; $14,04 \%$ de risco pertence à classe leste, de risco moderado, $14,5 \%$ de risco alto na classe nordeste, $18,73 \%$ na classe noroeste e oeste, com classificação de risco muito alto e $13,53 \%$ de risco extremo, com faces voltadas para o norte.

A fig. 3 representa o mapa de risco de incêndio florestal do Parque Nacional de Brasília. O resultado da equação gerou uma imagem cujos valores de pixels variam de 90 a 500 distribuídos em 9 classes, sendo que o grau de risco máximo em 500. Como as classes representadas foram apenas 5, efetuou-se uma classificação por intervalos constantes, de acordo com a classificação de risco estabelecida nesta metodologia: baixo, moderado, alto, muito alto e extremo.

A integração dos mapas de risco preliminares indica que $0,31 \%$ da área foram classificadas com risco baixo, $13,31 \%$ como risco moderado, $59,92 \%$ com risco alto, $23,31 \%$ com risco muito alto e $3,16 \%$ com risco extremo de incêndio florestal. As áreas de risco extremo estão localizadas principalmente na face norte e nordeste da lagoa de Santa Maria. Nestes locais a declividade é muito elevada e faz com que a propagação de um eventual incêndio seja mais rápida, aumentando o risco. A face sudeste do Parque apresentou elevado índice de risco de incêndio influenciado pelo tipo de vegetação de campo e

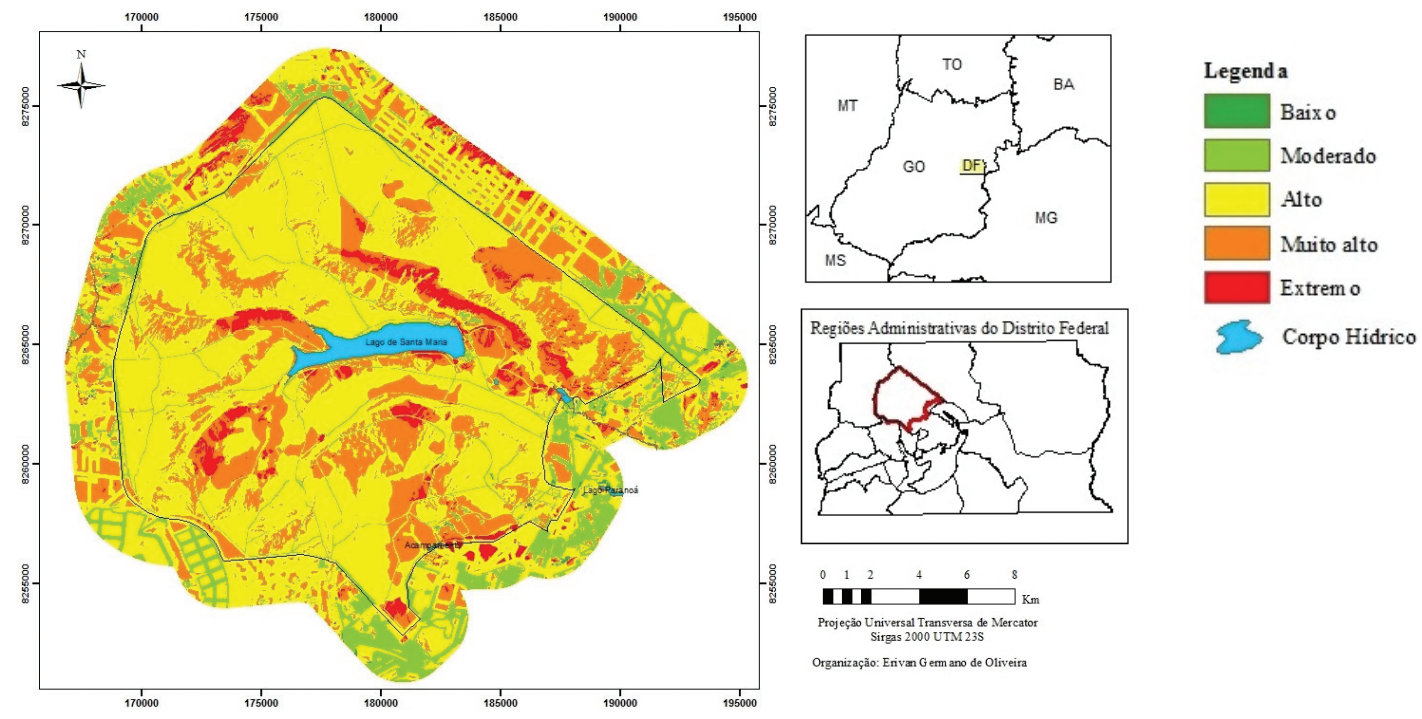

Fig. 3 - Mapa de risco de incêndio florestal.

Fig. 3 - Forest fire risk map. 
pela orientação das encostas, que apresentaram maiores valores de faces voltados para o norte.

Vários pontos do mapa apresentaram áreas de risco de incêndio influenciadas por todos os planos de informação utilizados nesta metodologia, porém, cabe priorizar as áreas limites do Parque, principais responsáveis pelo surgimento de focos. A face nordeste apresenta a presença de propriedades rurais que utilizam o fogo como ferramenta para limpeza do terreno, para fins agrícolas e para renovação de pastagens. A face sul e sudeste do Parque apresentam áreas de alto risco de incêndio, tendo em vista a presença humana responsável pelo depósito e queima de lixo nas áreas limites com o Parque.

De acordo com os Laudos periciais de incêndios florestais realizadas pelo Corpo de Bombeiros Militar do Distrito Federal - CBMDF do ano de 2000 a 2011, 90\% dos incêndios tiveram a sua origem fora dos limites do Parque, nas proximidades do seu perímetro. A principal causa foram os incendiários, seguidas pelas queimadas para limpeza de pastagem e agricultura, e por último, as de causa não identificadas.

De acordo com os resultados deste trabalho, observa-se que áreas próximas a aglomerados urbanos ou a áreas de uso antrópico (como por exemplo áreas de agricultura, nas quais são utilizadas queimadas para limpeza do solo) são as que mais contribuem para o início e propagação de incêndios. Em estudo realizado no município de Novo Mundo, Mato Grosso, Brasil, Ribeiro et al. (2012) mapearam o risco de ocorrência de incêndios florestais por meio de equações para cálculo de potencial de risco de incêndios, considerando a influência da hidrografia, da rede viária, da declividade do terreno e do uso e cobertura do solo. A partir do mapa, que classificou em seis níveis o risco de ocorrência de incêndio, os autores concluíram que a maior parte das áreas com risco extremo e muito alto estão próximas a locais com grande influência antrópica, tais como estradas e áreas de pastagens.

A fig. 4 demonstra a validação do modelo feita através da correlação das áreas de risco com dois incêndios, o que permitiu verificar a potencialidade das áreas de maior risco previstas neste modelo.

Em termos de área queimada, destacou-se o ano de 2007 e 2011, o incêndio florestal de 2007 totalizou uma área de 11.412 mil hectares e teve como foco inicial a queima de detritos vegetais em uma propriedade rural nos limites do Parque na face nordeste, de vegetação formada por pastagem, desenvolveu-se em áreas de suscetibilidade muito alta e extrema de incêndio e presença dos maiores índices de declividade do Parque.

O incêndio florestal de 2010 totalizou uma área de 12.953 mil hectares, teve como foco inicial o contato de chama direto com a vegetação, desenvolveu-se em áreas de suscetibilidade alta e muito alta de incêndio florestal. Para uma avaliação geral do modelo, seria necessário fazer uma comparação com outros focos de incêndios ocorridos nos últimos 11 anos, porém, os laudos periciais confeccionados pelo Corpo de Bombeiros apresentam insuficiência de informações que permitam identificar a localização do foco inicial dos incêndios.

Cabe ressaltar a importância dos dados climáticos na obtenção de índices de perigo de incêndio, não utilizados nesta metodologia. Os índices de umidade relativa de ar e quantidade de dias sem chuva nos permite avaliar a possibilidade de ocorrer um incêndio, assim como a facilidade de se propagar, de acordo com as condições atmosféricas do dia, ou de uma sequência de dias. A área de estudo deste trabalho situa-se em uma região de marcada estacionalidade climática - um período de seca bem marcado, que se estende entre os meses de abril a outubro - o que predispõe a um alto risco de ocorrência de incêndio à medida em que aumenta o número de dias sem chuva, que pode chegar a mais de 100 dias consecutivos. A pluviosidade média neste período varia de 15 a $60 \mathrm{~mm}$, sendo que a umidade relativa do ar chega a $10 \%$ nos meses de agosto e setembro, logo antes do início do período de chuvas.

\section{Mapa estratégico de combate a incêndio florestal}

A fig. 5 permite a identificação dos principais fatores que contribuem na prevenção e no combate aos incêndios florestais no Parque Nacional de Brasília, aliados aos fatores presentes no mapa de risco. A sobreposição do mapa estratégico de combate a incêndio ao mapa de risco de incêndio facilita a identificação de pontos de risco com maiores expectativas de ocorrência de fogo e a identificação de áreas que merecem maior vigilância, bem como a manutenção de aceiros, alocação de recursos em pontos estratégicos.

A utilização de um mapa estratégico de combate a incêndio torna-se útil na identificação de vias de acesso ao Parque, possíveis fontes de água para emprego no combate.

Fatores que contribuem para o combate aos incêndios florestais

Hidrantes - A localização dos hidrantes dentro do Parque é um fator importante, pois facilita o reabastecimento de viaturas de combate a incêndio, porém não tão importante quando se diz respeito a incêndios florestais, visto que tão logo acontecem os incêndios florestais, eles se propagam mata adentro, impedindo o avanço de viaturas de combate, permitindo somente o avanço de militares munidos de abafadores 
Portões - A facilidade de acesso ao Parque permite maior agilidade em acessar o foco inicial do incêndio, impedindo o seu avanço.

Estradas - As estradas são os meios mais importantes no combate aos incêndios, elas permitem o acesso

rápido para a localização do foco e posterior desembarque da tropa para o combate, facilita a extinção dos focos, pois funcionam como aceiros naturais.

Corpos hídricos - A localização dos corpos hídricos próximos aos focos de incêndios facilita no combate, visto que permite o combate com o lançamento de cargas de água com o bambibucket (equipamento utilizado por helicópteros para o combate a incêndio), e também no reabastecimento de bombas costais.

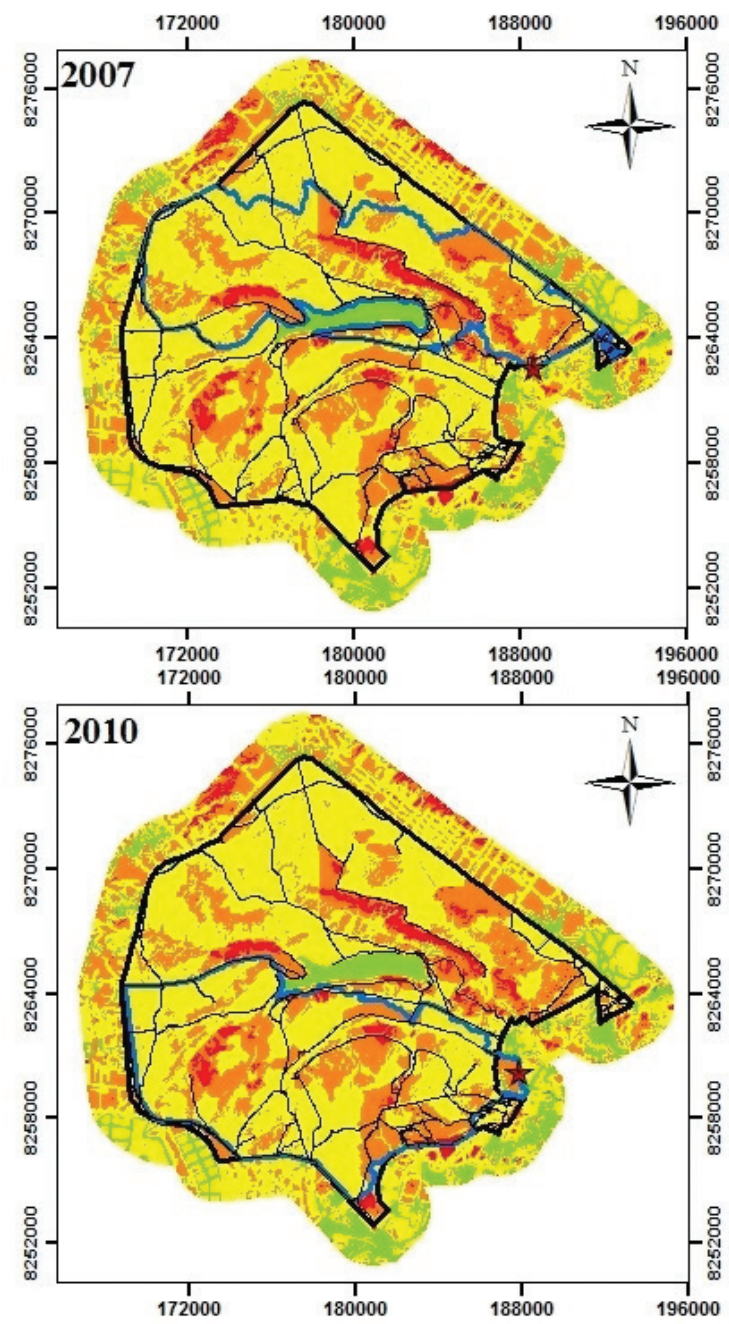

Legenda

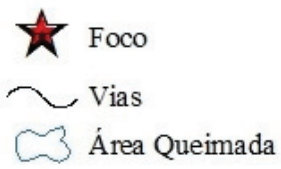

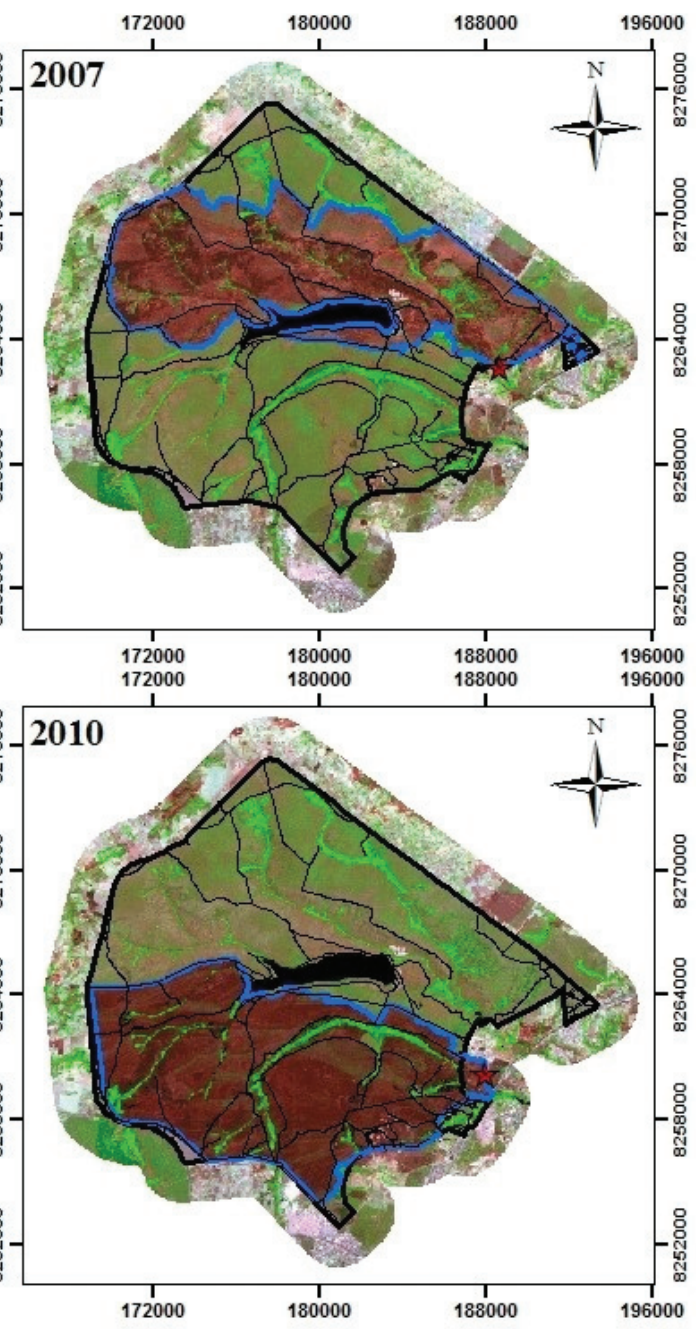

$\begin{array}{llllll}0 & 1 & 2 & 4 & 6 & 8\end{array}$

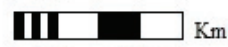

Projeção Universal Transversa de Mercator Sirgas 2000 UTM 23S

Organização: Erivan G erm ano de Oliveira

Fig. 4 - Incêndio Florestal dos anos 2007 e 2010.

Fig. 4 - Forest fires in 2007 and 2010. 
Distância da unidade Operacional - 0 tempo de identificação de um foco de incêndio e o acionamento de equipes de bombeiros pode ser um fator determinante na extinção do foco ou na sua rápida propagação, tendo em vista a facilidade de se combater um incêndio no seu estágio inicial.

Torres de observação - As torres de observação fazem parte do sistema de detecção de incêndios no Parque e são extremamente importantes na identificação do foco e rápida mobilização para o combate. As torres contam com a presença de equipes de brigadistas do IBAMA - Instituto Brasileiro do Meio Ambiente e dos Recursos Naturais Renováveis, responsáveis pela detecção dos focos de incêndios e primeiro combate.

\section{Conclusão}

A metodologia apresentada neste trabalho permitiu a identificação das áreas de risco de incêndio florestal no Parque Nacional de Brasília. Os resultados obtidos

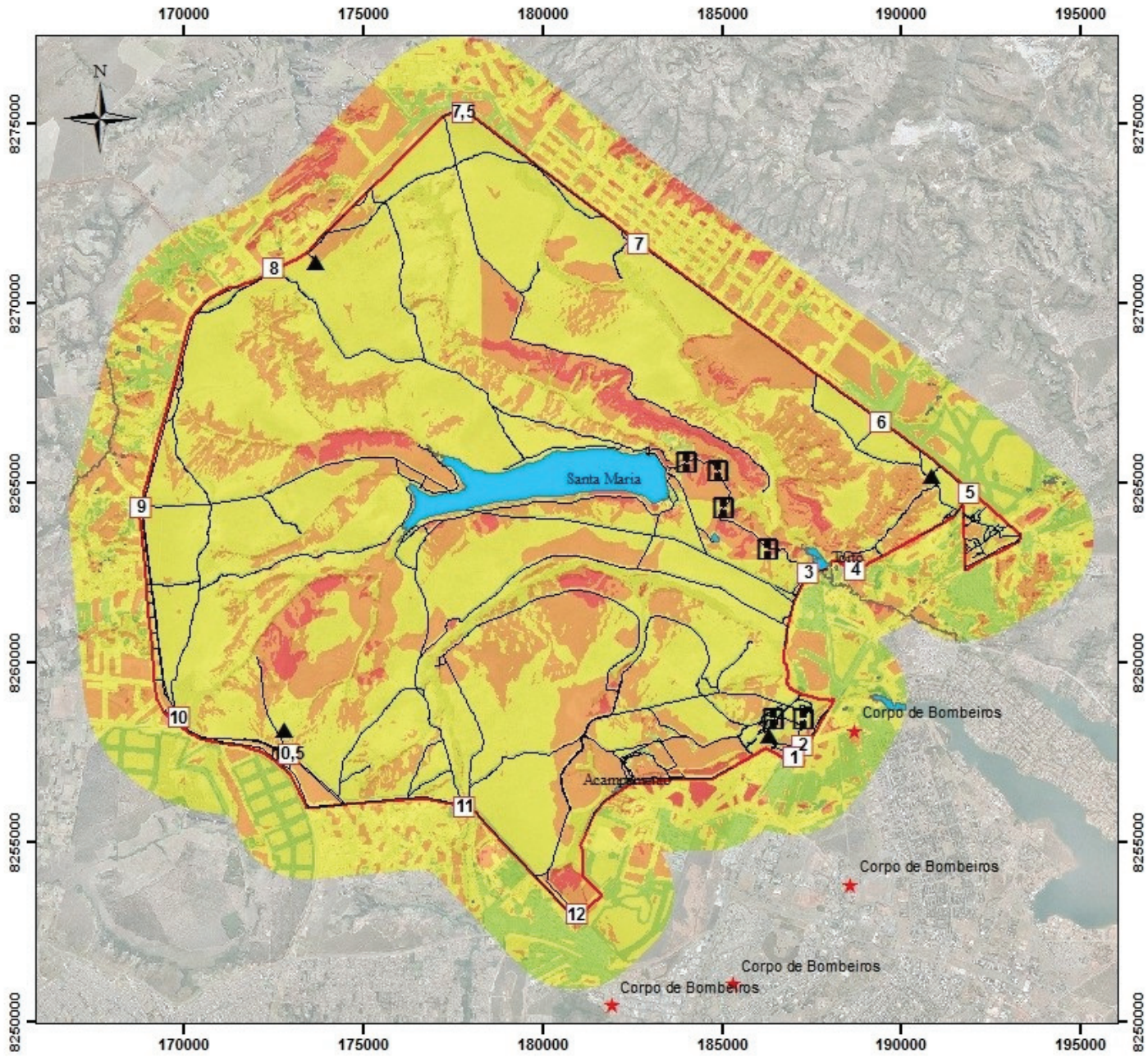

Legenda

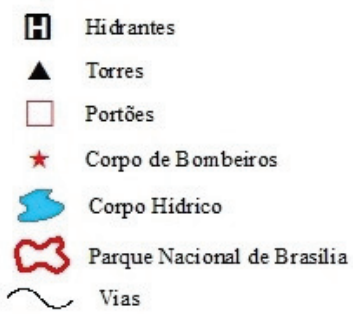

\section{Classes de Risco}

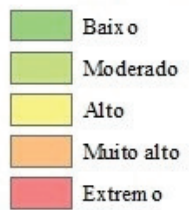

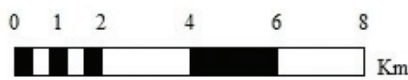

Projeção Universal Transversa de Mercator Sirgas 2000 UTM 23S

Organização: Erivan G erm ano de Oliveira

Fig. 5 - Mapa estratégico de combate a incêndio florestal.

Fig. 5 - Strategic firefighting map. 
demonstraram a necessidade de medidas preventivas durante o período de estiagem. As ações de prevenção e combate aos incêndios no Parque devem ser intensificadas, uma vez que foram observadas grandes áreas queimadas nos anos anteriores. Merecem maior atenção as faces norte e nordeste do Parque, onde são relatadas incidências maiores de incêndios em função das queimadas para o manejo de pastagens e agricultura. As faces sul e sudeste do Parque também apresentam áreas de alto risco de incêndio, tendo em vista a presença humana, responsável pelo depósito e queima de lixo nas áreas limites com o Parque.

0 estabelecimento de épocas de maior incidência de focos de incêndios permite ao Corpo de Bombeiros Militar do Distrito Federal e aos funcionários do Parque Nacional estruturar os programas de prevenção e combate, enquanto que a localização das regiões mais suscetíveis auxilia no mapeamento de risco e intervenção nas áreas que mereçam intervenção, para melhor proteger áreas mais sujeitas a perdas.

Os mapas de risco de incêndio têm a função de auxiliar os trabalhos de prevenção aos incêndios, orientando nas atividades de vigilância, manutenção de aceiros, conservação das estradas e alocação de equipes e equipamentos em pontos estratégicos para o combate. Informações como vias de acesso, pontos de captação de água são de extrema importância para as equipes de bombeiros, permitindo a organização das ações de combate com maior rapidez e eficiência.

A utilização de SIG viabiliza a detecção de locais de maior risco de incêndios florestais presentes no mapa de risco, o que o torna uma eficiente ferramenta no controle e monitoramento das áreas mais suscetíveis ao surgimento de focos, otimizando as ações de prevenção e combate aos incêndios.

\section{Referências bibliográficas}

Almeida, S. A. O. (1997). Determinação de redução de umidade superficial na região dos cerrados com imagens AVHRR/NOAA e precipitação pluviométrica (Tese de doutorado). Universidade de Brasília, Departamento de Ecologia. Brasília 20p.

Andrade, F. C., Ribeiro, G. S., Glerianl, J. M., Martins, M.C. (2011). Uso de fotografias aéreas não co nvencionais e SIG na elaboração de mapas de risco de incêndios florestais. In: Anais do Simpósio Brasileiro de Sensoriamento Remoto, Curitiba-PR p. 7925.
Batista, A. C. (2000). Mapas de risco: Uma Alternativa para o planejamento de controle de incêndios florestais. Floresta, Curitiba-PR, v. 30(1/2) p. 45-54.

CBMDF - CORPO DE BOMBEIROS MILITAR DO DISTRITO FEDERAL. Sistema de Engenharia de Segurança. Diretoria de Serviços Técnicos. Centro de Investigação e Prevenção de Incêndios. Laudos de Investigação de Incêndio $n^{\circ}$ 223/2000; 106/2002; 253/2003; 297/2003; 324/2003; 185/2004; 108/2005; $100 / 2006 ; 110 / 2007 ; 116 / 2007 ; 185 / 2007$; $167 / 2011$

Dias, B. F. S. (1992). Cerrados: uma caracterização. IN: Dias, B.F.S (Ed.) Alternativas de desenvolvimento dos cerrados: Manejo e conservação dos recursos naturais renováveis. Brasília-DF. IBAMA E FUNATURA, p. 11-25.

EMBRAPA - EMPRESA BRASILEIRA DE PESQUISA AGROPECUÁRIA. (1994). Atlas do meio ambiente do Brasil. Ed. Terra Viva. Brasília. 130p.

Ferraz, S. F. B., Vettorazzl, C. A. (1998). Mapeamento de risco de incêndios florestais por meio de sistema de informações geográficas (SIG). Scientia Forestalis, Piracicaba, v. 53, p. 39-48.

Ferreira, M.P ., Koproskl, L., Zanotta, D. C. (2011). Uma abordagem fuzzy no zoneamento de risco de incêndio. In: Anais XV Simpósio Brasileiro de Sensoriamento Remoto, Curitiba-PR. p.4555.

Koproskl, L., Ferreira, M. P., Goldammer, J. G., Batista, A.C. (2011). Modelo de zoneamento de risco de incêndios para unidades de conservação brasileiras: 0 caso do Parque estadual do cerrado (PR). Floresta, Curitiba-PR, v.41,n. 3, p.551-562.

Lierop, P., Lindquist, E., Sathyapala, S., Franceschini, G. (2015). Global forest area disturbance from fire, insect pests, diseases and severe weather events. Forest Ecology and Management, $\mathrm{n}$. 352, p. 78-88.

Medeiros, M. B., Fiedler, N. C. (2003). Incêndios Florestais no Parque Nacional da Serra da Canastra: Desafios para a Conservação da biodiversidade. Ciência Florestal, Santa Maria-RS, v. 14, n. 2, p. 157-168.

Oliveira, D. S. O., Batista, A. C., Soares, R. V., Grodzkl, L., Vosgerau, J. (2004) Zoneamento de Risco de Incêndios Florestais para o Estado do Paraná. Floresta, Curitiba, v. 34 n.2, p. 217, 221.

Ribeiro, R., Soares, V. S., Bepller, M. (2012). Mapeamento do Risco de incêndios florestais no município de Novo Mundo, Mato Grosso, Brasil. Cerne, Lavras-MG, v. 18, n. 1, p. 117-126.

Soares, R. V. (1985). Incêndios florestais: controle e uso do fogo. Curitiba-PR: Fundação de Pesquisas Florestais do Paraná. 213p. 

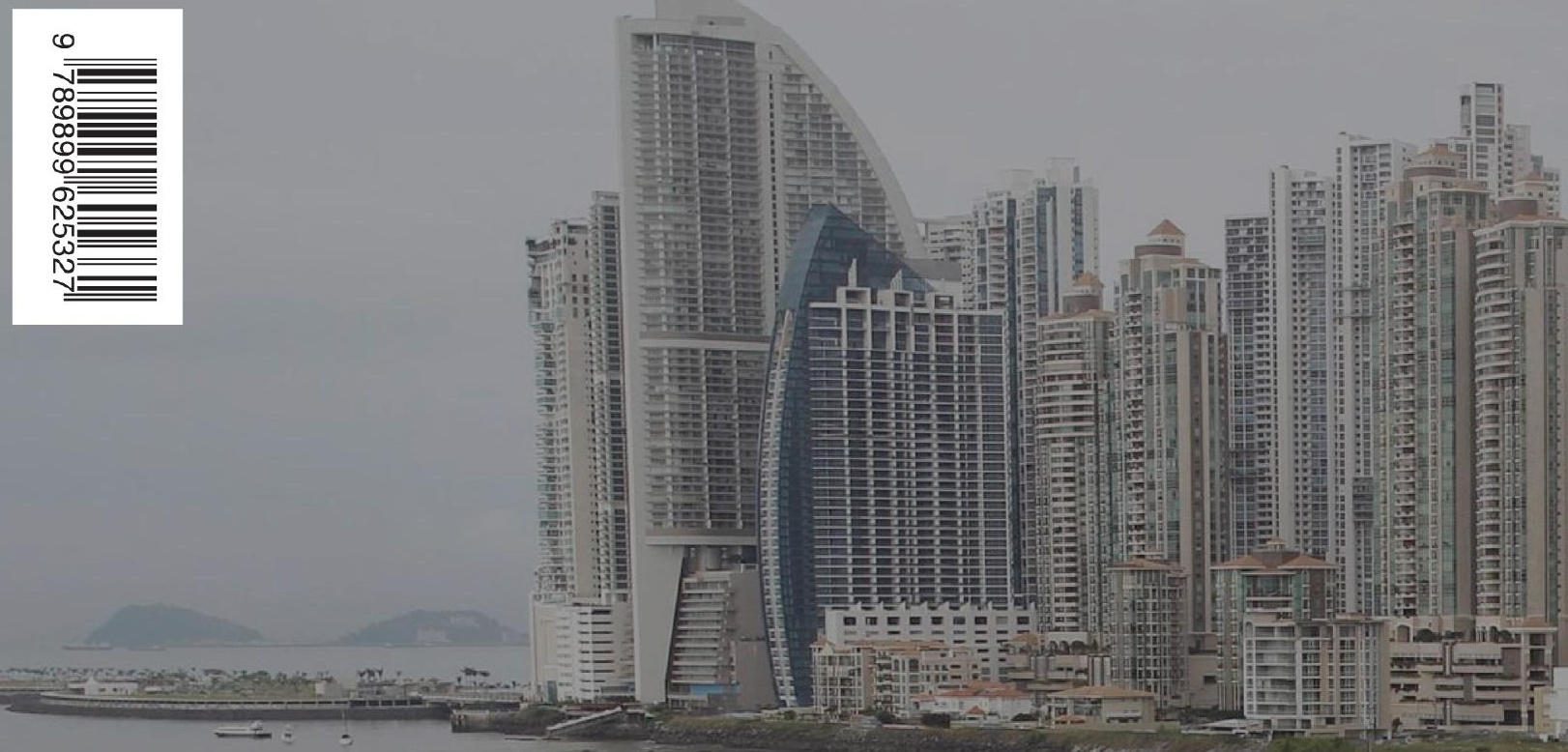

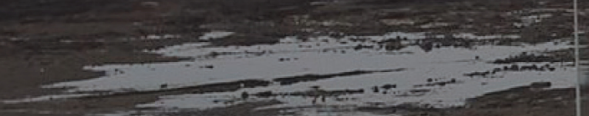

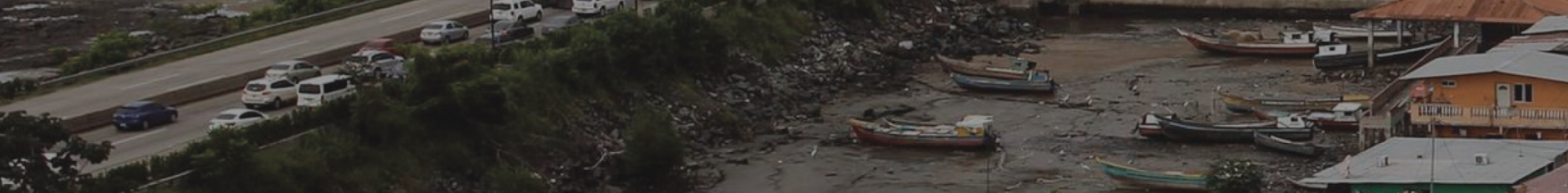

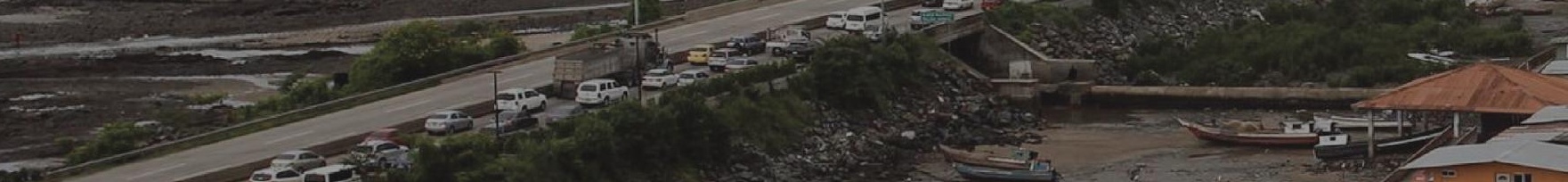
inse- $n=$ Riscos I I I

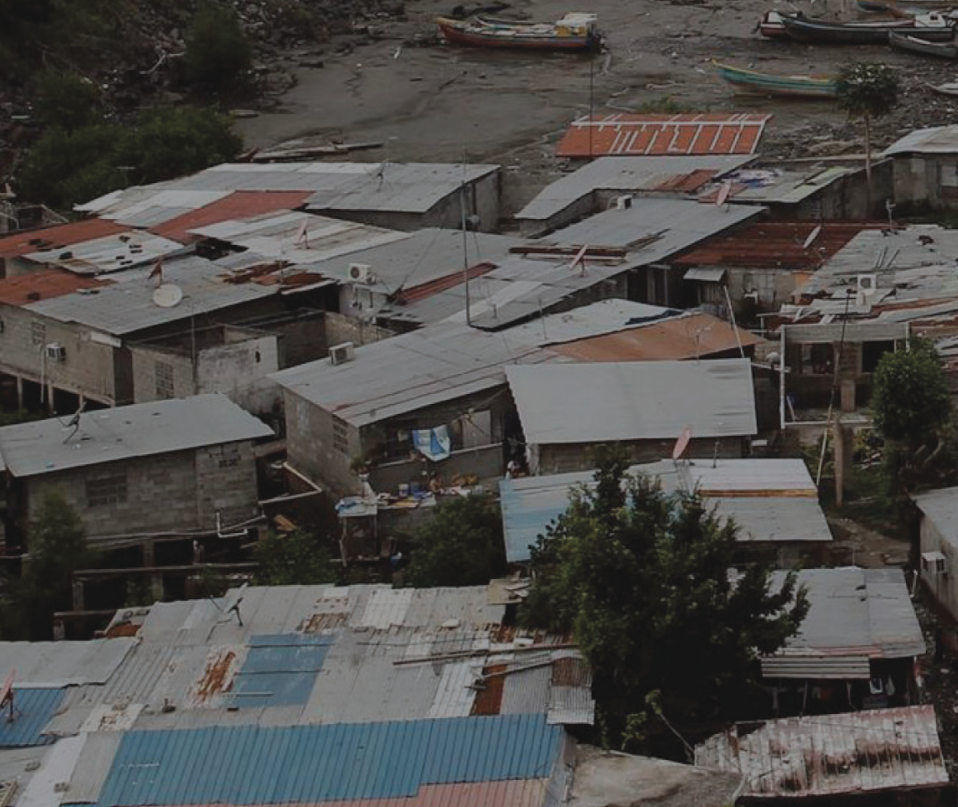

